\title{
PERANCANGAN ULANG TATA LETAK FASILITAS PRODUKSI UD. USAHA BERKAH BERDASARKAN ACTIVITY RELATIONSHIP CHART (ARC) DENGAN APLIKASI BLOCPLAN-90
}

\author{
JAKA DARMA JAYA ${ }^{\mathbf{*}}$, NURYATI ${ }^{1}$, SAFRIA AYU NUR AUDINAWATI ${ }^{1}$, \\ ${ }^{1}$ Jurusan Teknologi Industri Pertanian, Politeknik Negeri Tanah Laut, Jl. A. Yani, Km. 6, \\ Desa Panggung, Kec. Pelaihari, Kab. Tanah Laut, Kalimantan Selatan 70815, Indonesia. \\ *Email: jakadj2010@gmail.com
}

\begin{abstract}
The layout of factory facilities is the procedure of arranging factory facilities to support the fluency of optimal, effective, and efficient of production process.This research was conducted in tofu production at UD Usaha Berkah factory of Atu-atu Village, Pelaihari. The problem in UD Usaha Berkah was layout of facilities that are not in accordance with the degree of inter-facility relationships. The aims of these research was to design of the production layout facility to reduce a material flow. The design of the layout is done on all facilities of production department by using Blocplan application-90. This Blocplan application requires an activity relationship map or Activity Relationship Chart (ARC) between departments. Activity Relationship Chart (ARC) was obtained from direct interviews to respondents. The result of the interview was obtained by the relationship analysis of activity relationship by using the value of degree of proximity between departments. ARC data is used as input data on the Blocplan application. In the Blocplan90 application, the choice of layout based on three criteria, there are value of adjacency between facilities (Adjacency score), the value of layout efficiency (R-score), and total distance of material (Rel-dist score). Basic determination of best layout election on Blocplan-90 application that islayout which have value of efficiency (R-score) limit 1 score. Based on calculation analysis of Blocplan application resulted 20 alternative layout. The proposed layout is selected based on the highest $R$-score layout score. The best layout in these research has a $R$-score 0,89 from the 20 layout from the Blocplan-90 application.
\end{abstract}

Keywords: Activity Relationship Chart (ARC), Blocplan-90, Production Facilities, Layout

\begin{abstract}
ABSTRAK
Tata letak fasilitas pabrik adalah tata cara pengaturan fasilitas-fasilitas pabrik guna menunjang kelancaran proses produksi yang optimal, efektif dan efisien. Penelitian ini dilakukan pada pabrik pembuatan tahu UD Usaha Berkah Desa Atu-atu, Pelaihari. Permasalahan yang terdapat pada perusahaan ini adalah peletakan fasilitas yang tidak sesuai dengan derajat hubungan antar fasilitas. Penelitian ini bertujuan untuk merancang tata letak fasilitas dengan baik dan menghasilkan aliran material yang lancar, sehingga jarak tempuh material tidak terlalu panjang dan dapat mengurangi adanya arus bolak-balik aliran material proses produksi. Perancangan tata letak pabrik ini dilakukan pada seluruh fasilitas departemen produksi dengan menggunakan aplikasi Blocplan-90. Blocplan-90 ini membutuhkan data peta keterkaitan hubungan aktivitas atau Activity Relationship Chart (ARC) antar departemen. Data ARC diperoleh dari wawancara langsung kepada responden. Hasil dari wawancara diperoleh analisa keterkaitan hubungan aktivitas dengan menggunakan nilai derajat kedekatan antar departemen.
\end{abstract}


Langkah selanjutnya, data ARC digunakan sebagai data masukan pada aplikasi Blocplan90. Pada aplikasi Blocplan-90 didapatkan pilihan layout berdasarkan tiga kriteria, yaitu nilai kedekatan antar fasilitas (Adjacency score), nilai efisiensi layout ( $R$-score), dan total jarak tempuh material (Rel-dist score). Dasar penentuan pemilihan layout terbaik pada aplikasi Blocplan-90 yaitu layout usulan yang memiliki nilai efisiensi $(R$-score) mendekati 1. Berdasarkan analisis perhitungan aplikasi Blocplan-90 dihasilkan 20 alternatif layout usulan. Layout usulan dipilih berdasarkan pada nilai $R$-score layout tertinggi. Layout usulan terpilih pada penelitian ini mempunyai nilai $R$-score 0,89 , terbaik dari 20 layout usulan yang dihasilkan dari aplikasi Blocplan-90.

Kata kunci: Activity Relationship Chart (ARC), Blocplan-90, Fasilitas Produksi, Tata Letak

\section{PENDAHULUAN}

Tata letak fasilitas (facilities layout) adalah tata cara pengaturan fasilitasfasilitas pabrik guna menunjang kelancaran proses produksi. Tata letak fasilitas berhubungan erat dengan segala proses perencanaan dan pengaturan letak dari mesin, peralatan, aliran bahan dan manusia yang bekerja di masing-masing stasiun kerja yang ada (Nurhasanah dan Simawang, 2013). Perancangan fasilitas secara garis besar bertujuan untuk menentukan bagaimana aktivitas dan fasilitas produksi dapat diatur sehingga mampu menunjang upaya pencapaian tujuan pokok produksi secara optimal, efektif dan efisien. Selain itu perencanaan tata letak fasilitas juga bertujuan untuk menjamin kenyamanan, keselamatan dan kesehatan dalam bekerja.

UD Usaha Berkah yang berdiri sejak tahun 2014 merupakan salah satu industri pembuatan tahu yang berlokasi di Desa Atu-atu Kota Pelaihari. Tata letak fasilitas UD Usaha Berkah terdapat beberapa penempatan ruangan (departemen) yang kurang sesuai dengan aliran proses produksi atau hubungan kedekatan antar ruang yang terkait, sehingga jarak pemindahan bahan kurang efisien dan efektif serta mengurangi kenyamanan pekerja. Kurang tertatanya tata letak fasilitas dengan baik turut menjadi kendala proses produksi pada UD Usaha Berkah. Pada penelitian ini dilakukan evaluasi tata letak fasilitas produksi pada UD Usaha Berkah yang bertujuan untuk memberikan alternatif rancangan ulang tata letak fasilitas produksi yang lebih efisien dan efektif dilihat dari hubungan kedekatan antar aliran proses produksi dan meminimasi terjadinya aliran bolak-balik perpindahan bahan pada proses produksi. Pada penelitian ini digunakan metode hubungan keterkaitan atau 
Activity Relationship Chart (ARC) yang diolah menggunakan aplikasi Blocplan90.

Blocplan-90 merupakan sistem perancangan tata letak fasilitas yang dikembangkan oleh Donaghey dan Pire pada Departemen Teknik Industri, Universitas Houston pada tahun 1991. Blocplan-90 merupakan sebuah algoritma untuk pemecahan masalah tata letak ruang (layout) dan menangani data kuantitatif sebaik kualitatif. Hal utama yang ditanamkan pada Blocplan-90 berupa perbaikan atau algoritma penukaran dan pembangunan. Model matematis didalam perancangan yang dikembangkan dengan aplikasi komputer untuk model yang bekerja dengan batasan bentuk stasiun kerja (misal rectangular). Model tata letak dengan bentuk rectangular lebih diminati perusahan, dikarenakan keteraturan penempatan stasiun kerja dan kemudahan aliran kerja apabila dibandingkan dengan bentuk stasiun kerja yang tidak teratur. Keuntungan dari Blocplan-90 adalah kemudahan dalam penggunaan. Blocplan-90 memudahkan pengguna untuk mengubah data yang telah dimasukkan sebelumnya, memperbaiki posisi dari fasilitas dan dapat memasukkannya secara manual di lokasi yang diinginkan. Jika layout yang ada memiliki jumlah departemen yang sedikit atau departemen dengan luasan area yang hampir sama maka cocok untuk menggunakan aplikasi Blocplan90 karena akan menghasilkan solusi yang baik dengan waktu dan cara memasukkan input yang cepat dan mudah. Blocplan-90 juga mencetak tabel dari penyusunan layout yang menunjukkan nilai rel-dist seperti normalisasi $R$-score untuk tiap layout bersama dengan beberapa informasi lainnya (Wahyudi, 2010).

Program ini membuat dan mengevaluasi tipe-tipe tata letak dalam merespon data masukan. Blocplan-90 mempunyai kemiripan dengan CRAFT dalam penyusunan departemen. Perbedaannya adalah CRAFT hanya menggunakan peta dari-ke (from-to chart) sebagai input data, sedangkan Blocplan-90 dapat menggunakan peta dari-ke (from-to chart) atau menggunakan peta keterkaitan (ARC), tetapi kedua input tersebut hanya digunakan salah satu saja saat melakukan evaluasi tata letak. Tata letak tidak dapat dilakukan evaluasi dengan mengkombinasikan kedua data, peta keterkaitan dan data aliran. Biaya tata letak 
dapat diukur baik berdasarkan ukuran jarak maupun dengan kedekatan (Pratiwi, dkk., 2012).

Activity Relationship Chart (ARC) atau peta hubungan keterkaitan aktivitas adalah suatu cara atau teknik yang sederhana dalam merencanakan tata letak fasilitas atau departemen berdasarkan derajat hubungan aktivitas yang sering dinyatakan dalam penilaian kualitatif dan cenderung berdasarkan pertimbanganpertimbangan yang bersifat subyektif dari masing-masing fasilitas/departemen (Mieftah, 2009). Peta keterkaitan aktivitas digunakan untuk menganalisis tingkat hubungan atau keterkaitan aktivitas dari suatu ruangan dengan ruangan lainnya. Peta keterkaitan aktivitas dapat menghubungkan aktivitas-aktivitas secara berpasangan sehingga semua aktivitas akan diketahui tingkat hubungannya dan dapat membantu mengetahui suatu ruangan perlu didekatkan atau dijauhkan dari ruangan lainnya (Pratiwi, dkk., 2012).

\section{METODE PENELITIAN}

\section{Pengumpulan Data}

Pengumpulan data di pabrik tahu UD Usaha Berkah menggunakan metode observasi untuk mengenal kondisi awal tata letak fasilitas, serta metode wawancara untuk mengumpulkan data proses pembuatan tahu, data ukuran departemen produksi, layout awal dan hubungan keterkaitan aktivitas antar departemen (Activity Relationship Chart/ ARC). Proses wawancara dilakukan dengan tatap muka secara langsung dengan responden yang terdiri dari 2 (dua) karyawan dan 1 (satu) pemilik pabrik. Wawancara dilakukan dengan mengajukan pertanyaan, meminta penjelasan dan jawaban dari pertanyaan yang diberikan dan membuat catatan mengenai hal-hal yang diungkapkan. Data utama yang dikumpulkan yaitu proses pembuatan tahu dan pengisian kuesioner mengenai hubungan keterkaitan aktivitas antar departemen.

Selanjutnya dilakukan identifikasi dan perumusan masalah untuk menentukan pemecahan masalah tata letak yang ada. Serta dilakukan studi literatur/ studi pustaka dari berbagai literatur mengenai perancangan tata letak fasilitas, untuk 
penyelesaian masalah dan mengenali sistem yang akan dipelajari dalam pemecahan masalah yang terjadi (Dewi, dkk., 2012; Nursandi, dkk., 2014).

Pabrik Tahu Usaha Berkah berlokasi di Jalan H.M. Djapri RT 03 RW 01 Desa Atu-atu, Pelaihari. Pabrik ini mempekerjakan 2 (dua) orang karyawan dan 1 (satu) pemilik yang juga terjun dalam pengolahan. Pabrik Tahu Usaha Berkah merupakan usaha kecil menegah dengan kapasitas pengolahan $800 \mathrm{Kg}$ kedelai/hari, memiliki luas pabrik $900 \mathrm{~m}^{2}$ dengan peralatan pengolahan yang masih berteknologi sederhana.

\section{Pengolahan Data}

Pertama-tama dilakukan penggambaran layout awal produksi yang dilakukan dengan meninjau dari tata letak pabrik yang ada saat ini (Siregar, 2013). Layout awal UD Usaha Berkah dapat dilihat pada Gambar 1.

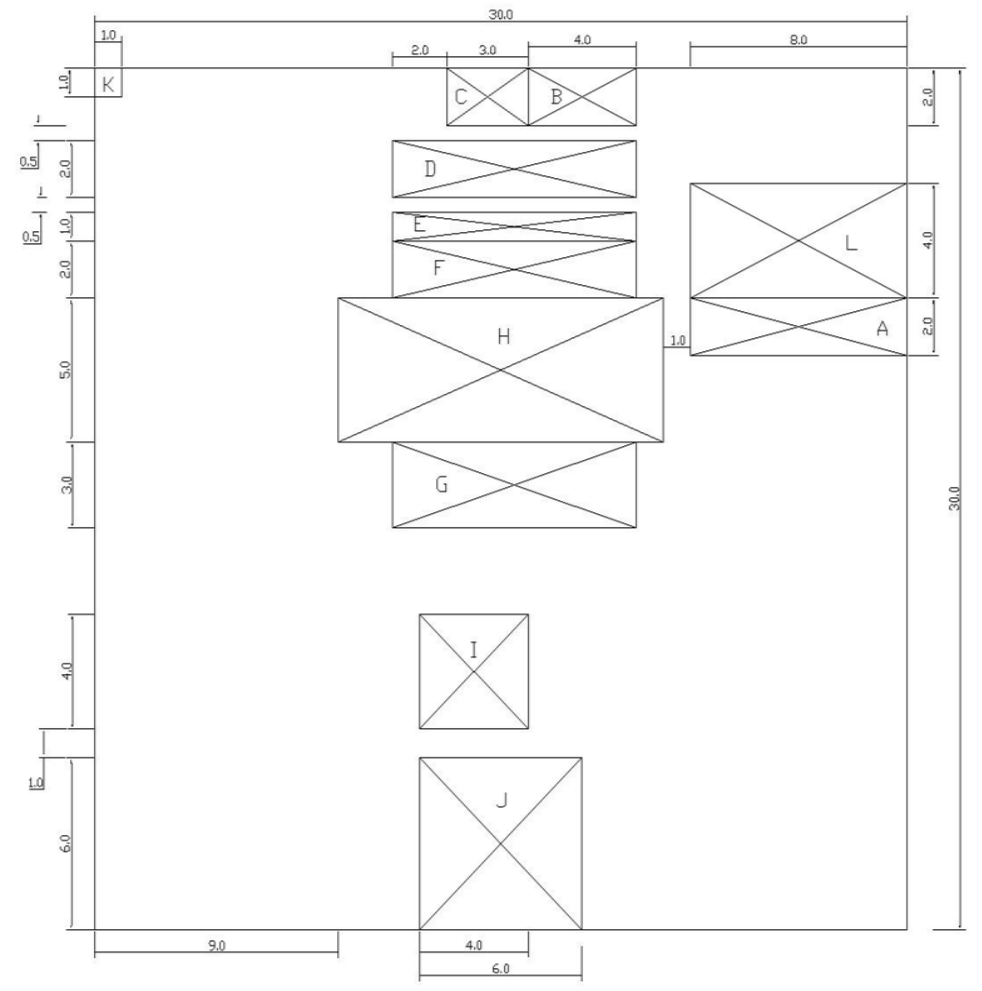

Keterangan:
A : Gudang bahan baku
E : Penyaringan
I : Ketel uap
B : Perendaman
$\mathrm{F}$ : Pengendapan dan pencetakan
$\mathrm{H}$ : Produk jadi
C : Penggilingan
$\mathrm{G}:$ Pemotongan
$\mathrm{K}$ : Sumur
D : Pemasakan
$\mathrm{H}$ : Produk jadi
L : Parkiran

Gambar 1. Layout Awal UD Usaha Berkah 
Kemudian, dibuat hubungan kedekatan menggunakan Activity Relationship Chart (ARC) berdasarkan pertimbangan aliran perpindahan material antar tiap departemen yang telah didapatkan dari wawancara. ARC digunakan sebagai data kuantitatif yang diperlukan sebagai data input aplikasi Blocplan-90 (Siregar, 2013).

Selanjutnya dilakukan perancangan tata letak menggunakan aplikasi Blocplan-90 seperti berikut:

a. Melakukan input data departemen yaitu mengenai jumlah departemen, nama departemen dan ukuran luas masing-masing departemen.

b. Melakukan input data derajat kedekatan antar departemen yang telah dituliskan pada ARC.

c. Pilihan tata letak, Blocplan-90 akan menampilkan lima buah pilihan rasio panjang dan lebar dari bentuk tata letak yang diinginkan.

d. Mencari solusi layout terbaik, kriteria yang digunakan untuk pemilihan alternatif layout adalah adjacency score (nilai hubungan kedekatan antar fasilitas), R-score (efisiensi layout), dan Rel-dist Score (jarak). Pertimbangan dari tiga jenis kriteria, $R$-Score memiliki tingkat kepentingan paling tinggi dan memberikan pengaruh paling besar dalam pemilihan alternatif tata letak fasilitas, jadi layout yang terbaik adalah layout dengan $R$-Score mendekati 1 atau paling tinggi (Dewi, dkk., 2012).

\begin{abstract}
Alat
Alat yang digunakan untuk mendukung penelitian ini adalah alat tulis kantor, alat pengukur satuan meter, laptop, komputer dengan OS XP, aplikasi Blocplan 90 (developed by Donaghey and Pire) dan printer.
\end{abstract}

\title{
HASIL DAN PEMBAHASAN
}

\section{Activity Relationship Chart (ARC)}

Hubungan keterkaitan fasilitas yang diperoleh dari hasil wawancara dengan responden UD Usaha Berkah kemudian dimasukkan dalam metode ARC. Proses wawancara dilakukan dengan tatap muka secara langsung dengan responden yang 
terdiri dari 2 (dua) karyawan dan 1 (satu) pemilik pabrik. Pertanyaan-pertanyaan yang diajukan pada saat wawancara dibatasi tentang proses pembuatan tahu, data ukuran departemen produksi, layout awal dan hubungan keterkaitan aktivitas antar departemen (Activity Relationship Chartl ARC). Metode wawancara dilakukan untuk mendapatkan data yang akurat dan membantu responden agar dapat memahami dengan benar hal teknis yang ditanyakan saat wawancara. Rekap ARC hasil wawancara dapat dilihat pada Gambar 2.

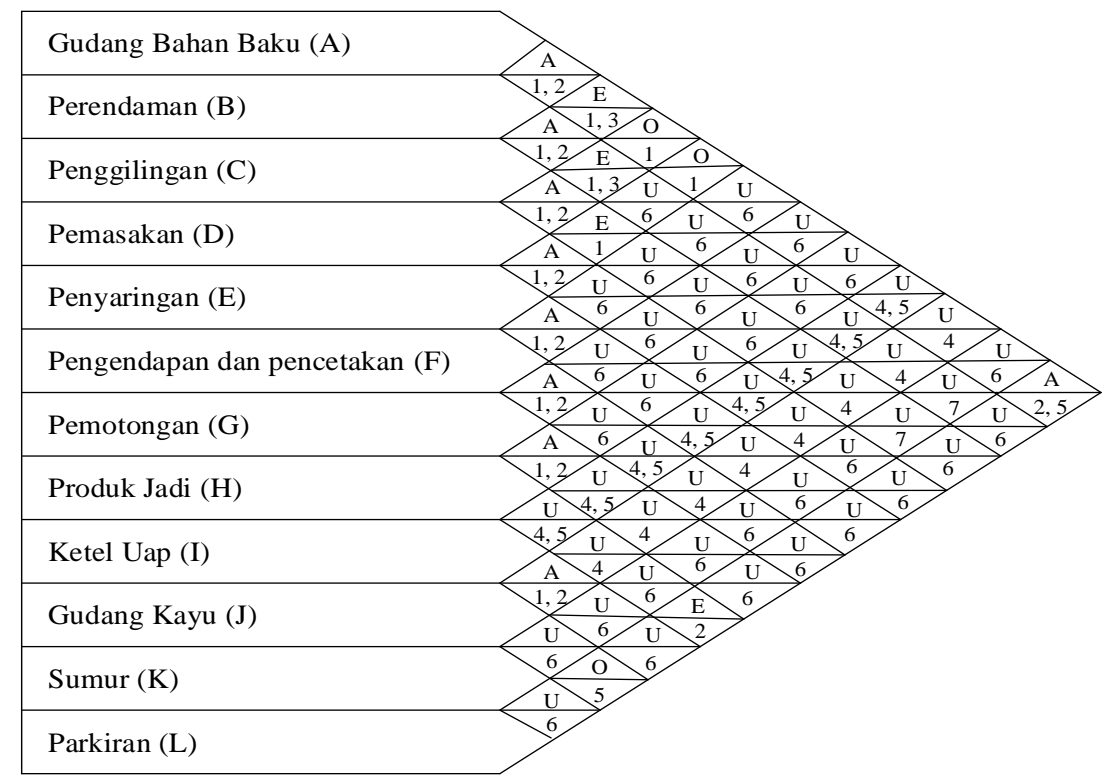

\footnotetext{
Keterangan:

$\mathrm{A}=$ Mutlak didekatkan

$\mathrm{E}=$ Sangat penting didekatkan

$\mathrm{I}=$ Penting didekatkan

$\mathrm{O}=$ Cukup/ biasa

$\mathrm{U}=$ Tidak penting didekatkan

$\mathrm{X}=$ Tidak dikehendaki berdekatan
}

\author{
Kode alasan: \\ $1:$ Urutan aliran kerja \\ 2: Aliran material \\ 3: Menggunakan tenaga kerja yang sama \\ 4 : sumber kontaminasi (bising, bau, debu, kotor) \\ 5 : Keselamatan dan kenyamanan pekerja \\ 6 : Tidak ada hubungan kerja \\ 7 : Dapat menggunakan alat sebagai perantara
}

\section{Gambar 2. ARC Hasil Wawancara}

Pada UD Usaha Berkah departemen-departemen yang mutlak untuk didekatkan yaitu departemen gudang bahan baku dengan perendaman, departemen perendaman dengan penggilingan, departemen penggilingan dengan pemasakan, departemen pemasakan dengan penyaringan, departemen penyaringan dengan pengendapan dan pencetakan, departemen pengendapan dan pencetakan dengan pemotongan, departemen pemotongan dengan tempat produk jadi, ketel uap dengan 
gudang kayu serta parkiran dengan gudang bahan baku. Departemen yang sangat penting didekatkan yaitu gudang bahan baku dengan penggilingan, perendaman dengan pemasakan, penggilingan dengan penyaringan, serta tempat produk jadi dengan parkiran. Sedangkan departemen yang cukup/biaa untuk didekatkan yaitu gudang bahan baku dengan pemasakan, gudang bahan baku dengan penyaringan, serta gudang kayu dengan parkiran. Selain pasangan departemen yang telah disebutkan memiliki derajat hubungan yang tidak penting untuk didekatkan.

Perancangan tata letak fasilitas pabrik perlu mempertimbangkan hubungan keterkaitan antar fasilitas dengan alasan aliran proses produksi, aliran material, kualitas produk serta keselamatan dan kenyamanan pekerja. Bertujuan untuk meminimalkan aliran bolak-balik proses produksi yang dapat menghambat atau memperlama proses produksi (Faishol, 2013). Selain itu, penempatan departemen pada UD Usaha Berkah lebih tertata rapi sesuai urutan proses dan tingkat kepentingan sehingga tercipta usaha produksi yang lebih efektif dan efisien.

\section{Tata Letak Fasilitas dengan Aplikasi Blocplan-90}

Berdasarkan hasil dari ARC maka langkah selanjutnya adalah merancang tata letak fasilitas dengan menggunakan aplikasi Blocplan-90. Blocplan-90 bekerja secara Hybrid Algorithm yaitu membangun dan mengubah tata letak dengan mencari total jarak tempuh yang minimal dengan melakukan pertukaran antar stasiun kerja/fasilitas. Prinsip kerja dari aplikasi Blocplan-90 adalah mencari layout terbaik dengan menggunakan pertimbangan skor dari derajat kedekatan ARC dengan cara Automatic search yang secara otomatis dilakukan penempatan area secara random (Wahyudi, 2010). Hasil dari iterasi Blocplan-90 didapatkan seperti pada Tabel 1. 
Tabel 1. Hasil Iterasi Blocplan-90

\begin{tabular}{|c|c|c|c|c|}
\hline Layout & Adj. Score & \multicolumn{2}{|c|}{ Rel-Dist Score } & $\begin{array}{l}\text { Produk } \\
\text { Momen }\end{array}$ \\
\hline 1 & $0,75-9$ & $0,76-8$ & $761-9$ & $0-1$ \\
\hline 2 & $0,54-20$ & $0,73-14$ & $949-16$ & $0-1$ \\
\hline 3 & $0,70-16$ & $0,65-19$ & $1038-19$ & $0-1$ \\
\hline 4 & $0,75-9$ & $0,75-10$ & $848-10$ & $0-1$ \\
\hline 5 & $0,80-4$ & $0,84-4$ & $720-5$ & $0-1$ \\
\hline 6 & $0,80-4$ & $0,75-11$ & $878-13$ & $0-1$ \\
\hline 7 & $0,80-4$ & $0,72-15$ & $968-18$ & $0-1$ \\
\hline 8 & $0,80-4$ & $0,72-17$ & $952-17$ & $0-1$ \\
\hline 9 & $0,71-15$ & $0,74-13$ & $867-12$ & $0-1$ \\
\hline 10 & $0,62-19$ & $0,64-20$ & $1063-20$ & $0-1$ \\
\hline 11 & $0,75-9$ & $0,82-7$ & $758-8$ & $0-1$ \\
\hline 12 & $0,94-1$ & $0,75-12$ & $756-7$ & $0-1$ \\
\hline 13 & $0,70-16$ & $0,72-16$ & $928-14$ & $0-1$ \\
\hline 14 & $0,89-2$ & $0,87-3$ & $703-4$ & $0-1$ \\
\hline 15 & $0,75-9$ & $0,83-6$ & $731-6$ & $0-1$ \\
\hline 16 & $0,84-3$ & $0,84-5$ & $684-3$ & $0-1$ \\
\hline 17 & $0,70-16$ & $0,71-18$ & $939-15$ & $0-1$ \\
\hline 18 & $0,75-9$ & $0,89-1$ & $614-1$ & $0-1$ \\
\hline 19 & $0,76-8$ & $0,75-9$ & $863-11$ & $0-1$ \\
\hline 20 & $0,75-9$ & $0,89-1$ & $614-1$ & $0-1$ \\
\hline
\end{tabular}

. $R$-score menunjukkan efisiensi layout, dimana $R$-score tertinggi adalah layout terbaik. Nilai $R$-score adalah nilai normalisasi Rel-dist score dengan memperhitungkan batas atas dan batas bawah yang semua datanya sudah ditampilkan pada hasil analisa aplikasi Blocplan-90 pada setiap layout usulan. Nilai $R$-Score (normalized relationship distance score) yang mendekati nilai 1 menunjukan bahwa layout tersebut optimal (Wahyudi, 2010). Layout terbaik dipilih nomor 18 dan 20 dengan nilai $R$-score yang sama yaitu 0,89 . Gambar layout terbaik yang terpilih menggunakan aplikasi Blocplan-90 dapat dilihat pada Gambar 3. 


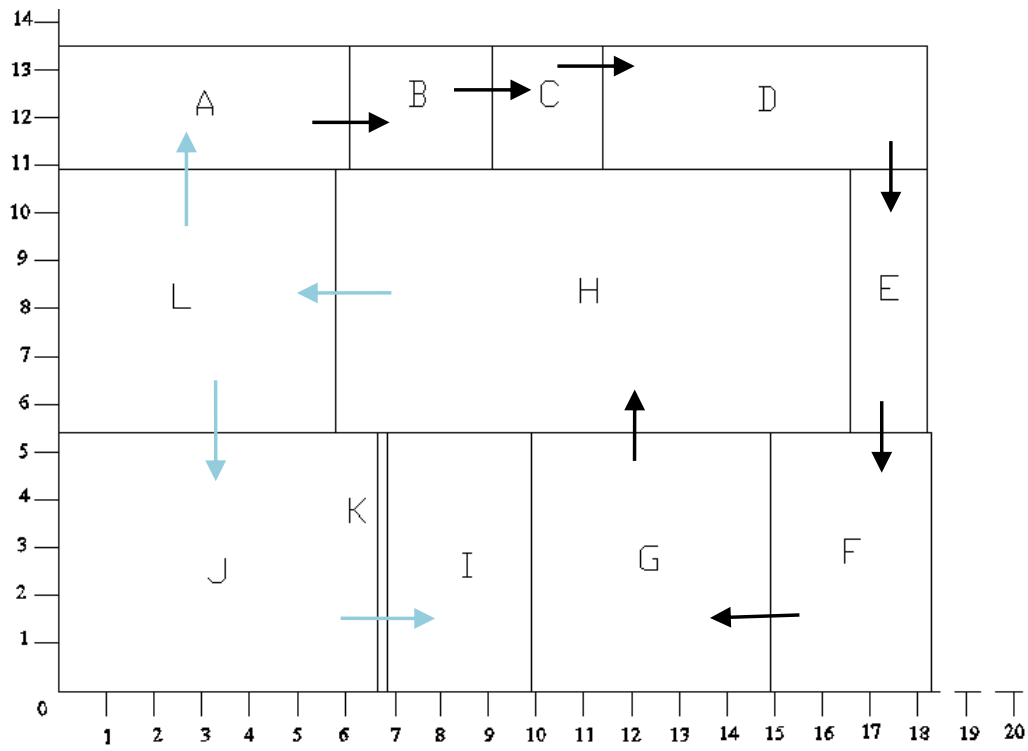

Gambar 3. Layout Terbaik Hasil Blocplan-90

Hasil dari aplikasi Blocplan-90 kemudian disesuaikan dengan keadaan area seperti terlihat pada Gambar 4.

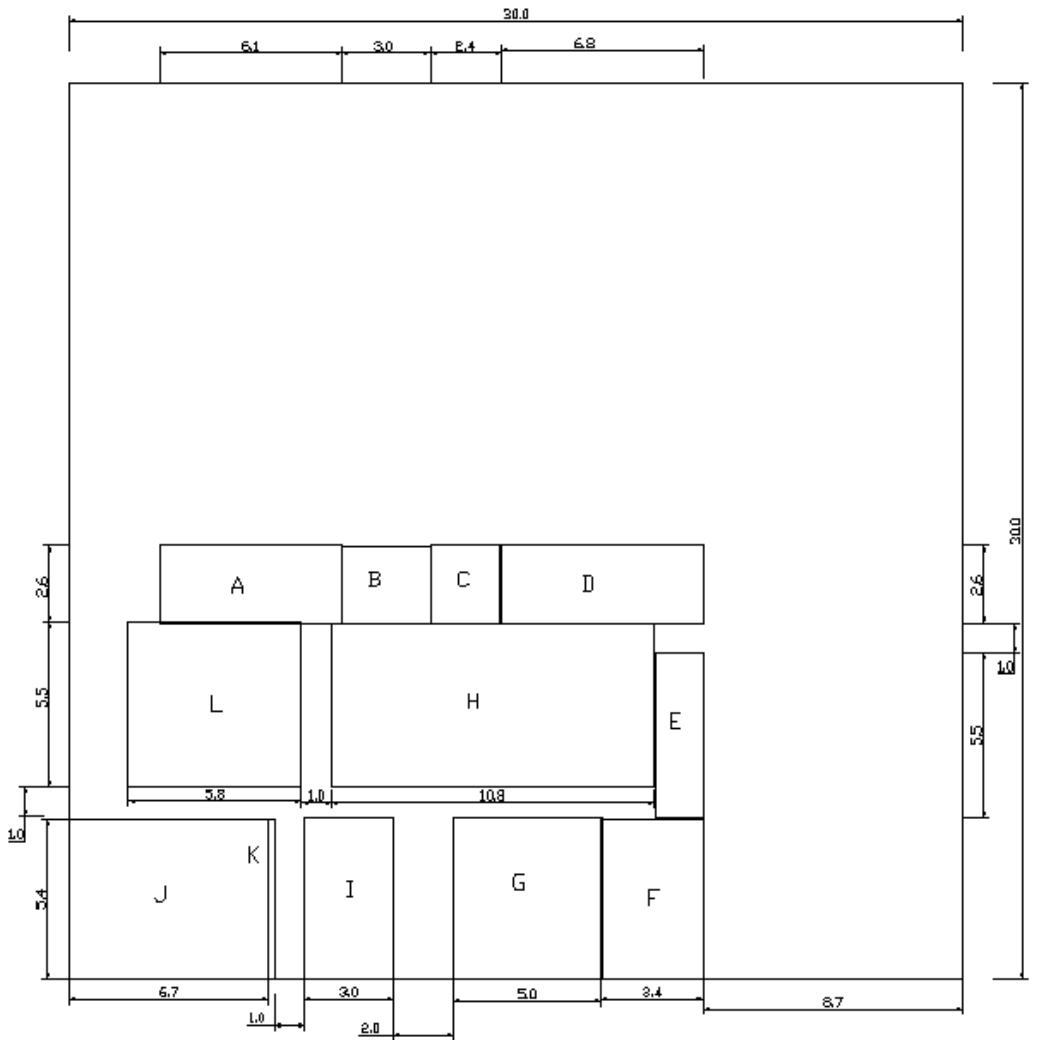

Gambar 4. Penyesuaian Layout Hasil Blocplan 
Alternatif layout yang dihasilkan dari metode Blocplan-90 sesuai dengan data kualitatif ARC, dapat dilihat bahwa tata letak fasilitas produksi tertata rapi sesuai dengan aliran proses pembuatan tahu. Penempatan fasilitas pada alternatif layout mengalami perubahan pada departemen gudang bahan baku yang diletakkan dekat dengan tempat parkir untuk memudahkan pemindahan material berupa kedelai. Perubahan tata letak juga terdapat pada pemindahan departemen pemotongan setelah departemen pengendapan dan pencetakan untuk menyesuaikan aliran bahan dan aliran proses produksi tahu. Selain itu, departemen-departemen proses produksi telah tertata sesuai dengan urutan aliran proses produksi.

Pada departemen gudang kayu mengalami perubahan yaitu letaknya yang memiliki jarak lebih dekat dengan tempat parkir daripada sebelumnya, untuk memudahkan dan memberikan kenyamanan bagi pekerja dalam memindahkan material berupa kayu bahan bakar ketel uap. Penempatan ketel uap yang diletakkan berjauhan dengan departemen-departemen produksi dapat mengurangi hawa panas yang dapat mengganggu aktivitas pekerja dalam pabrik, sehingga keselamatan dan kesehatan pekerja terjamin (Faishol, 2013). Penempatan tersebut juga dapat mengurangi terjadinya kontaminasi silang pada produk tahu berupa debu, kotoran dan bau yang dihasilkan dari keter uap. Penempatan fasilitas produksi pada alternatif baru tidak terjadi aliran bolak-balik. Hal ini terlihat pada alternatif layout yang telah tersusun sesuai urutan aliran proses produksi tahu, sehingga nantinya dapat menghasilkan produksi yang optimum, efisien dan efektif.

Walaupun perancangan ulang tata letak pada penelitian ini dapat memberikan alternatif aliran material yang efisiendan dapat mengurangi adanya arus bolak-balik aliran material, akan tetapi secara teknis BLOCPLAN mempunyai kelemahan yaitu tidak akan menangkap initial layout secara akurat. Pengembangan tata letak hanya dapat dicari dengan melakukan perubahan atau pertukaran letak departemen satu dengan lainnya (Pratiwi, dkk., 2012). Selain itu dalam aplikasinya alternatif layout yang dihasilkan membutuhkan investasi dana untuk pengaturan ulang tata letak departemen dan alat produksi. 


\section{KESIMPULAN}

Berdasarkan hasil dari pengolahan data dan analisa mengenai perancangan ulang tata letak fasilitas produksi pada pabrik tahu UD Usaha Berkah dapat disimpulkan bahwa perancangan ulang tata letak fasilitas dengan menggunakan Activity Relationship Chart (ARC) menghasilkan tata letak yang sesuai aliran proses produksi dan dihasilkan alternatif layout terbaik dari aplikasi Blocplan-90 dengan nilai $R$-score 0,89 .

\section{UCAPAN TERIMA KASIH}

Terima kasih ditujukan kepada Politeknik Negeri Tanah Laut terutama Program Studi Teknologi Industri Pertanian dan pihak UD Usaha Berkah atas dukungan dalam pelaksanaan penelitian ini.

\section{DAFTAR PUSTAKA}

Dewi, R., Choiri, M. dan Eunike, A. 2012. Perancangan Tata Letak Fasilitas Menggunakan Metode Blocplan dan Analytic Hierarchy Process (AHP) (Studi Kasus: Koperasi Unit Desa Batu). Universitas Brawijaya.

Faishol, M., Hastuti, S. dan Ulya, M. 2013. Perancangan Ulang Tata Letak Fasilitas Pabrik Tahu Srikandi Junok Bangkalan. Agrointek, Vol. 7, No. 2.

Nurhasanah, N. dan Simawang, B. 2013. Perbaikan Rancangan Tata Letak Lantai Produksi di CV.XYZ. Jurnal Al-Azhar Indonesia Seri dan Teknologi. Vol. 2, No. 2.

Nursandi, Mustofa, F. dan Rispianda. 2014. Rancangan Tata Letak Fasilitas dengan Menggunakan Metode Blocplan (Studi Kasus PT. Kramatraya Sejahtera). Jurnal Online ITN. Reka Integra. Vol. 01, No. 03.

Pratiwi, I., Muslimah, E., dan Aqil, A., 2012. Perancangan Tata Letak Fasilitas di Industri Tahu Menggunakan Blocplan. Jurnal Ilmiah Teknik Industri, Vol. 11, No. 2.

Siregar, R., Sukatendel, D. dan Tarigan, U. 2013. Perancangan Ulang Tataletak Fasilitas Produksi dengan Menerapkan Algoritma Blocplan dan Algoritma Corelap. e-Jurnal Teknik Industri FT USU Vol 1, No. 1. 
Wahyudi, E., 2010. Perancangan Ulang Tata Letak Fasilitas Produksi di CV.

Dimas Rotan Gatak Sukoharjo. (Skripsi) Universitas Sebelas Maret, Surakarta. 